\title{
Review and Prospect of Music Therapy for Intervention of Test Anxiety
}

\author{
Xiang Li ${ }^{1}$,Yi Liu ${ }^{2}$,Jian-quan Liu ${ }^{3}$,Zhi-bing Zhong,

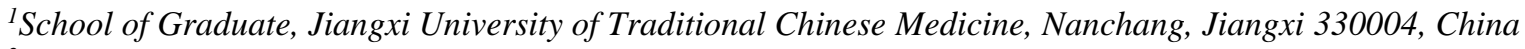 \\ ${ }^{2}$ School of Graduate, Jiangxi University of Traditional Chinese Medicine, Nanchang, Jiangxi 330004, China \\ ${ }^{3}$ School of Graduate, Jiangxi University of Traditional Chinese Medicine, Nanchang, Jiangxi 330004, China \\ ${ }^{4}$ Psychological Counseling Center, Jiangxi University of Traditional Chinese Medicine, Nanchang, Jiangxi 330004, \\ China \\ *Corresponding author. Email:494234679@qq.com
}

\begin{abstract}
Test anxiety is a negative emotion produced by individuals in the test environment. Serious test anxiety will cause psychological and physical adverse reactions, which will not only affect the test results, but also affect the healthy development of students' body and mind. As a new subject, music therapy has achieved great results in the treatment of mental and physical diseases, as well as the regulation of self-emotion and the promotion of interpersonal communication. This paper, by searching related articles of music therapy intervention for test anxiety, collates, analyzes and summarizes the results of such studies, explores the effectiveness of music therapy intervention for test anxiety. At the same time, it proposes future research trends and directions in this research field :(1) Optimize the experimental design;(2) Improve treatment techniques to enhance intervention effectiveness; (3) Adopt multi-dimensional index to measure; (4) Expanding intervention research on different groups.
\end{abstract}

Keywords: Music therapy; test anxiety; intervention; experimental study; social sciences

\section{INTRODUCTION}

Test anxiety is a kind of anxiety that occurs when people take the test or during the test. Compared with foreign countries, although the study of examination anxiety in China is relatively late, the psychologist Zheng Richang [1] defines examination anxiety more comprehensively. He thinks that examination anxiety is stimulated by some examination-oriented situations, and because of the restriction of individual evaluation ability, physical and mental factors, personality characteristics, there is a psychological state characterized by worry as the main feature, with defense or evasion as the behavior mode, through the reaction of different emotions.In view of the concept of test anxiety, many foreign scholars have studied different mechanisms and models to explore the causes of test anxiety and the relationship between academic achievement and mental health status. A large number of studies have shown that examination anxiety has become a more common psychological problem in the student group, and serious examination anxiety will cause psychological and physical adverse reactions, which will not only affect the students' learning and examination results, but also affect the healthy development of the students' body and mind.

Former president of the American music therapy association Bruscia argues that "music therapy is a process of systematic intervention in which therapists use various forms of music experience, as well as therapeutic relationships developed during the treatment process, as therapeutic agents to help therapeutic subjects achieve health goals [2] ." Music is not only a form of expression of emotion, but the public can induce different emotional experiences in the process of listening to music, which can regulate the physiological function of different systems of the body, and can improve the function of digestive system, endocrine system and mental nervous system. As early as the 20th century, music therapy, as a way to relieve anxiety and reduce stress, has been widely used in different fields and groups, such as hospice care, stage tension, depression, autism and neurosis.

\section{MATERIALS AND METHODS}

\subsection{Literature Retrieval Strategy}

The research literature on the intervention of music therapy on exam anxiety from CNKI, WANFANG and VIP were searched. CNKI, WANGFANG and VIP were searched by computer, with "music therapy" or "music therapy" and "exam anxiety" or "pre-exam anxiety" as keywords or subject words. The retrieval time was from June 5, 2020 when each database was built. 


\subsection{Literature Collection and Screening}

Through computer retrieval, 190 related literatures were retrieved, and repeated literatures were deleted, and 158 literatures were obtained. The selection criteria were as follows:(1) language was limited to Chinese;(2) experimental research, meta-analysis and qualitative research literature on music therapy intervention examination anxiety. Finally, 16 articles were obtained by screening.

Table 1 Experimental study on music therapy intervention for test anxiety

\begin{tabular}{|c|c|c|c|c|c|}
\hline $\begin{array}{c}\text { Autho } \\
\mathbf{r}\end{array}$ & Participant & $\begin{array}{c}\text { Intervention } \\
\text { techniques }\end{array}$ & $\begin{array}{c}\text { Interventio } \\
\text { n Group }\end{array}$ & $\begin{array}{l}\text { Control } \\
\text { group }\end{array}$ & Result \\
\hline $\begin{array}{l}\text { Yang } \\
\text { Shaoxi } \\
\mathrm{a}[3]\end{array}$ & $\begin{array}{l}\text { Third-year } \\
\text { junior high } \\
\text { school } \\
\text { students }\end{array}$ & $\begin{array}{l}\text { Music Group } \\
\text { Tutoring }\end{array}$ & $\begin{array}{l}\text { A. } n=14 \\
\text { B. } n=14 \\
\text { Once a week } \\
(60 \mathrm{~min} / \text { time })\end{array}$ & $\mathrm{n}=14$ & $\begin{array}{l}\text { There were significant differences between intervention } \\
\text { group A, intervention group B and control group. } \\
\text { Musical psychological counseling could significantly } \\
\text { reduce test anxiety and state-trait anxiety scores, as well } \\
\text { as blood pressure and heart rate. }\end{array}$ \\
\hline $\begin{array}{l}\text { Zhu } \\
\text { Yan[4] }\end{array}$ & undergraduate & $\begin{array}{l}\text { Music group } \\
\text { game }\end{array}$ & $\begin{array}{l}\mathrm{n}=37 \\
\text { Once a } \\
\text { week, } 10 \\
\text { times in total }\end{array}$ & $\mathrm{n}=37$ & $\begin{array}{l}\text { The test anxiety in the intervention group was } \\
\text { significantly reduced while the test anxiety in the } \\
\text { control group was not significantly changed. }\end{array}$ \\
\hline $\begin{array}{l}\text { Jiang } \\
\text { Dan } \\
\text { ping[5] }\end{array}$ & $\begin{array}{l}\text { Junior college } \\
\text { students }\end{array}$ & $\begin{array}{l}\text { Orff Group } \\
\text { Music Therapy }\end{array}$ & $\begin{array}{l}\mathrm{n}=12 \\
\text { Twice a week } \\
\text { (40min/time) }\end{array}$ & $\begin{array}{l}\text { no control } \\
\text { group }\end{array}$ & $\begin{array}{l}\text { The scores of the students with moderate test anxiety } \\
\text { fell back to between } 0 \text { and } 9 \text { points, that is, the test } \\
\text { anxiety was eliminated or reduced to mild } \\
\text { uncontrollable anxiety. }\end{array}$ \\
\hline $\begin{array}{l}\text { Chen } \\
\text { Yuxia } \\
\text { et al } \\
{[6]}\end{array}$ & $\begin{array}{l}\text { Junior high } \\
\text { school } \\
\text { students }\end{array}$ & $\begin{array}{l}\text { Progressive } \\
\text { muscle relaxation } \\
\text { exercises in } \\
\text { music and } \\
\text { Instructional } \\
\text { music } \\
\text { imagination }\end{array}$ & $\begin{array}{l}\mathrm{n}=32 \\
\text { Once a week } \\
(45 \mathrm{~min} / \\
\text { time) }\end{array}$ & $\begin{array}{l}\text { no control } \\
\text { group }\end{array}$ & $\begin{array}{l}\text { After intervention, there was no statistically significant } \\
\text { difference in scores between the subjects with low and } \\
\text { medium anxiety. Subjects with high anxiety scored } \\
\text { significantly lower after intervention. Instructional } \\
\text { music imagination was more effective for girls and } \\
\text { students with high test anxiety. }\end{array}$ \\
\hline $\begin{array}{l}\text { Zhou } \\
\text { Yingh } \\
\text { ua et al } \\
\text { [7] }\end{array}$ & $\begin{array}{l}\text { College } \\
\text { students and } \\
\text { undergraduate }\end{array}$ & $\begin{array}{l}\text { Progressive } \\
\text { muscle relaxation } \\
\text { exercises in } \\
\text { music }\end{array}$ & $\begin{array}{l}\mathrm{n}=20 \\
\text { Once a } \\
\text { day,30 times } \\
\text { in } \\
\text { total }\end{array}$ & $\begin{array}{l}\text { no control } \\
\text { group }\end{array}$ & $\begin{array}{l}\text { After intervention, students' anxiety scores were } \\
\text { significantly reduced, systolic blood pressure, diastolic } \\
\text { blood pressure and respiratory rate gradually decreased, } \\
\text { and pulse values before and after intervention showed } \\
\text { little change. }\end{array}$ \\
\hline $\begin{array}{l}\text { Zhang } \\
\text { Minya } \\
\text { n } \\
{[8]}\end{array}$ & $\begin{array}{l}\text { Junior high } \\
\text { school } \\
\text { students }\end{array}$ & $\begin{array}{l}\text { Progressive } \\
\text { muscle relaxation } \\
\text { exercises in } \\
\text { music }\end{array}$ & $\begin{array}{l}\mathrm{n}=34 \\
\text { Twice a week } \\
(35 \mathrm{~min} / \text { time })\end{array}$ & $n=34$ & $\begin{array}{l}\text { The anxiety level of the intervention group was lower } \\
\text { than that of the control group, and the difference was } \\
\text { significant. }\end{array}$ \\
\hline $\begin{array}{l}\text { Liu } \\
\text { Chun } \\
\text { yan et } \\
\text { al } \\
\text { [9] }\end{array}$ & $\begin{array}{l}\text { Junior high } \\
\text { school } \\
\text { students }\end{array}$ & $\begin{array}{l}\text { Listening to } \\
\text { music }\end{array}$ & $\begin{array}{l}\mathrm{n}=20 \\
\text { Twice a week } \\
\text { (30min/time) }\end{array}$ & $\mathrm{n}=20$ & $\begin{array}{l}\text { In the intervention group TAI, there were significant } \\
\text { differences in emotional factors before and after } \\
\text { measurement, while there were no significant } \\
\text { differences in anxiety factors. In the pre-and post-test } \\
\text { comparison of the intervention group, TAI scores of } \\
\text { subjects with mild test anxiety were significantly } \\
\text { different, those with moderate test anxiety were } \\
\text { significantly different, and those with severe test } \\
\text { anxiety were not significantly different. }\end{array}$ \\
\hline $\begin{array}{l}\text { Qin } \\
\text { Xiong } \\
\text { et al } \\
{[10]}\end{array}$ & undergraduate & $\begin{array}{l}\text { Listening to } \\
\text { music }\end{array}$ & $\begin{array}{l}\mathrm{n}=90 \\
\text { Twice a week } \\
\text { (30min/ time) }\end{array}$ & $\mathrm{n}=55$ & $\begin{array}{l}\text { In the intervention group, the total anxiety scores, } \\
\text { anxiety scores and emotionality scores of test anxiety } \\
\text { symptom factors all decreased significantly. }\end{array}$ \\
\hline $\begin{array}{l}\text { Sun } \\
\text { Aixue } \\
\text { et al } \\
{[11]}\end{array}$ & $\begin{array}{l}\text { College } \\
\text { students } \\
\text { preparing to } \\
\text { take } \\
\text { postgraduate }\end{array}$ & $\begin{array}{l}\text { Listening to } \\
\text { music }\end{array}$ & $\begin{array}{l}\mathrm{n}=55 \\
\text { Once a week } \\
(20 \mathrm{~min} / \text { time })\end{array}$ & $\mathrm{n}=62$ & $\begin{array}{l}\text { There were significant differences between the } \\
\text { intervention group and the control group in the exam } \\
\text { anxiety scores, anxiety and emotionality, and the scores } \\
\text { decreased significantly. }\end{array}$ \\
\hline
\end{tabular}


exams

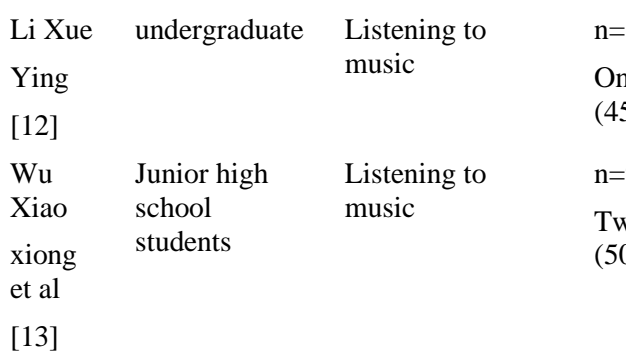

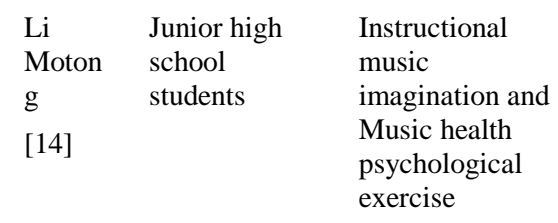

$\begin{array}{ll}\text { He } & \text { High school } \\ \text { Jin[15] } & \text { students }\end{array}$

$\begin{array}{ll}\text { Li } & \text { Junior high } \\ \text { Xiaoxi } & \text { school } \\ \text { a } & \text { students }\end{array}$

[16]

\section{Zhu}

Xiao

Feng

[17]

\section{Liu}

Xiao

chen[1

8]

\section{Junior high}

school

students

\section{$\mathrm{n}=8$}

Once a week

(45min/ time)

$\mathrm{n}=90$

Twice a week (50min/ time)

$$
\mathrm{n}=20
$$

Twice a week (45min/ time) ercise

\section{Auricular plaster} therapy and five elements music therapy

Kinesiology and Music Group Tutoring

\section{Systematic} desensitization and musical relaxation training

\section{College}

students preparing to take postgraduate exams

\section{Vibroacoustic} Therapy

\section{A. $n=20$ \\ B. $n=20$}

C.n=20

Twice a week (40min/ time)

$\mathrm{n}=10$

Once a week (30min/ time)

\section{$\mathrm{n}=15$}

Three times a

week

(60min/ time)

$\mathrm{n}=29$

Once a day (30min/ time) no control

group

no control

group

.

$n=20$

In the intervention group, the post-test anxiety, emotionality and total score were significantly lower than the pre-test scores. Students with mild test anxiety get the fastest improvement, while students with moderate and severe test anxiety need to step by step.

no control Auricular point pressing and five elements music group combined intervention had obvious effect on the physical and psychological symptoms of exam anxiety, and there were significant differences between the combined group and the two control groups.

The total scores of anxiety test in the intervention group and the control group were lower than those in the pretest, but the total scores of anxiety test in the intervention group were significantly lower.

$\mathrm{n}=50 \quad$ The anxiety level of students decreased obviously before and after intervention.

In the intervention group, anxiety symptoms were significantly relieved after 10 and 20 days of treatment. In the control group, anxiety symptoms were not significantly relieved after 10 days of treatment and 20 days of treatment.

\section{RESEARCH METHODS OF MUSIC THERAPY INTERVENTION FOR TEST ANXIETY}

\subsection{Randomized Controlled Eexperiments were Designed}

Among the music therapy intervention studies on test anxiety as of June 5, 2020 (see Table 1), the number of randomized controlled trials was 10 , accounting for $62.5 \%$ of the total. Randomized controlled trials can balance confounding factors to a large extent, thus improving the effectiveness of statistical tests.

\subsection{Diversity of Music Therapy Techniques}

It can be seen from Table 1 that the current music therapy techniques for exam anxiety intervention are diversified, mainly focusing on three aspects: music therapy group counseling, music muscle progressive relaxation training and music listening, which are all accepted music therapy techniques. Some experimental studies (Zhu Xiaofeng, He Jin, Li Xiaoxia) not only use music therapy technology, but also innovatively combine music therapy with psychology technology, traditional Chinese medicine health therapy, dance therapy, to explore the effect of combined intervention test anxiety.

\subsection{Comprehensive Measuring Tool}

In the retrieval of the thesis, this paper adopts a kind of and above the regulators or the questionnaire, most of the 
papers used by the United States, a clinical psychologist Spielverger [19] prepare the test anxiety inventory (TAI) and by the United States, a clinical psychologist in the department of psychology at the university of Washington Irwin G. Sarason [20] professor compiled by test anxiety scale (TAS), both scale is widely used in the world of test anxiety scale. At the same time, some experimental studies also adopted the anxiety self-rating scale (SAS) and the SCL-90 symptom self-rating scale, which are highly targeted to assess the level and degree of exam anxiety. In addition, some studies have added physiological indicators. It provides a more favorable basis for the research effect of music therapy intervention on test anxiety and makes the experimental results more objective.

\section{AN ANALYSIS OF THE EFFECTIVENESS OF MUSIC THERAPY FOR TEST ANXIETY}

In general, music therapy interventions for test anxiety are supported by sufficient credible evidence. In the randomized controlled experimental study, the test anxiety scores of students in the intervention group all decreased to varying degrees, and all improved the anxiety level to some extent, while the control group basically remained unchanged, and there were significant differences between the intervention group and the control group. In the experimental design, the anxiety scores of students in the experimental group were significantly reduced after intervention, and the differences between the two groups were significant. Studies have shown that music therapy in combination with other techniques has significant effects on test anxiety interventions.

\section{LIMITATIONS AND PROSPECTS OF THE RESEARCH}

\subsection{Optimize the Experimental Design}

In randomized controlled trials, without regular intervention and active control, it is difficult to infer whether the change in the final data was due to the intervention itself, or to a reduction in test anxiety due to self-regulation or cognitive change. Increasing active control is beneficial to further clarify the effect of the intervention measures adopted in the study and improve the reliability and validity of the experimental results. In addition, the requirements for subjects in randomized controlled trials generally require a certain amount, and the statistical treatment based on this is of reliable significance. The number of subjects in the above papers is different, and most of the studies do not mention the method to determine the number of subjects, nor do they have specific procedures and schemes to randomly assign subjects. If the method is not accurate, it may lead to data bias. Therefore, in the future research, the experimental design scheme should be optimized to make the experimental data accurate and real.

\subsection{Improve Treatment Techniques to Enhance Intervention Effectiveness}

Among the studies comparing different levels of exam anxiety, the research results of Liu Chunyan et al. and $\mathrm{Li}$ Motong show that students with mild exam anxiety get the fastest improvement after intervention, while students with moderate and severe exam anxiety need to improve gradually. However, in Chen Yuxia's study, there was no statistically significant difference between the scores of subjects with low and medium anxiety before and after the test, while the scores of subjects with high anxiety were significantly reduced after intervention. Such a result is worth thinking. In the future research, different technologies can be used to conduct targeted intervention for subjects with different levels of test anxiety, so as to better improve the level of test anxiety of subjects. The combined intervention technology has different effects on the physical and psychological of test anxiety subjects. In He Jin experiments, for example, the auricular application pressure for somatic symptoms improve large subjects, five lines of music therapy to the intervention effect of subjects of psychological symptoms, and the joint intervention of exam anxiety's body and psychological symptoms are obviously improved, but to improve the effect of test anxiety levels as separate five lines of music therapy intervention to improve. This may be due to individual differences among subjects, or it may be due to experimental operation design, which can be further studied and discussed. At the same time, the intervention effect of music therapy technology on test anxiety should also be explored. For example, the combination of group counseling and case counseling can make the research more in-depth and convincing.

\subsection{Adopt Multi-Dimensional Index to Measure}

The psychological measurement mostly USES the selfreport scale, the measurement result is easily affected by the subject's subjective intention, while the physiological index reflects an objective value. Using multi-dimensional index as the measure of intervention effect can increase the persuasiveness and reliability of experimental results. In the future, more kinds of physiological indicators can be added in this research field to measure, so as to provide more favorable basis for intervention effect. 


\subsection{Expanding Intervention Research on Different Groups}

At present, the research on test anxiety intervention mainly focuses on middle school students and college students as well as postgraduate entrance examination students, without specific analysis on specific problems of specific groups of students. In future studies, relevant intervention studies can be conducted on specific groups such as graduate students, career editors and civil servants. Whether the research techniques in the above literatures are applicable still needs to be further studied and discussed.

\section{CONCLUSION}

In this paper, the effectiveness of music therapy intervention on test anxiety was explored by searching the research on music therapy intervention on test anxiety and sorting, analyzing and summarizing the results. Meanwhile, in view of the shortcomings and limitations in such articles, the future research trend and direction in this field were proposed.

\section{ACKNOWLEDGMENT}

This work was supported by Jiangxi provincial education and science "13th five-year plan" 2020 annual project(No.146) and Project supported by the subject of Research on College Students' Leadership Training under the DoubleEducation Mode (2018jzzd-1).

\section{REFERENCES}

[1] Zheng Richang et al. Diagnosis and treatment of exam anxiety $[\mathrm{M}]$. Heilongjiang Science and Technology Publishing Industry, 1990:35.

[2] Gao Tian. Basic theory of music therapy [M]. World Book Publishing Company.2007

[3] Yang Shaoxia. Research on the Effectiveness of Music Therapy Group Psychological Counseling Manual in alleviating middle school students' exam anxiety [D]. Yunnan Normal University,2015. DOI: CNKI: CDMD:2.1015.903777

[4] Zhu Yan. Empirical research on the effectiveness of music group games in relieving the exam anxiety of music majors $[\mathrm{J}]$. Journal of chuxiong normal university,2011,26(04):73-80. DOI: 10.3969/j.issn.16717406.2011.04.013
[5] Jiang Danping. Strategy research on orff's music therapy intervention for medical students' exam anxiety [J]. Journal of kaifeng education institute, 2019,39(04):166-167. DOI: 10.3969/j.issn.10089640.2019.04.077

[6] Chen Yuxia, Zhang Shaohua, Wei Chushan, Yang Yuneng, Mai Jincheng. Analysis on the effect of instructional music imagination on relieving test anxiety of senior high school students [J]. China school health,2012,33(12):1488-1489.

DOI:

CNKI:SUN:XIWS.0.2012-12-032

[7] Zhou Yinghua, Xue Hui, Zhang Caijuan. Intervention of progressive muscle relaxation on exam anxiety of medical students $[\mathrm{J}]$. Chinese journal of health psychology,2013,21(04):538-540.

DOI:CNKI:SUN:JKXL.0.2013-04-026

[8] Zhang Minyan. On the relieving effect of Music relaxation Technology on students' anxiety in examination [J]. Education and Occupation,2005(35):137-138. DOI: 10.3969/j.issn.1004-3985.2005.35.070

[9] Liu Chunyan. Experimental Study on the effect of receiving Music therapy on relieving examination anxiety of middle school students [D]. Sichuan Normal University,2007. DOI:CNKI:CDMD:2.2007.198248

[10] Qin Xiong, Zhao Xuanliang, Yang Xiaobo. Effect of receiving music therapy on relieving exam anxiety of medical students [J].Journal of guangxi medical university,2012,29(05):720-721. DOI:10.3969/j.issn.1005930X.2012.05.019

[11] Sun Aixue, Zhou Xuexue, Cheng Shuying. Effect of music therapy on relieving anxiety of college students taking postgraduate entrance exams [J]. Chinese journal of health psychology,2012,20(02):320-321.

DOI:CNKI:SUN:JKXL.0.2012-02-069

[12] Li Xueying. Experimental study on music therapy to relieve college students' anxiety on English test [J]. Journal of henan university of engineering (social science edition),2011,26(03):91-93. DOI: 10.3969/j.issn.16743318.2011 .03 .022

[13] Wu Xiaoxiong, Zhang Bin, Li Kefu. Experimental Study on music Therapy to alleviate exam anxiety of junior high school students [J]. The Guide to Knowledge, 2019 (15):13-14.

[14] Li Motong. Practical Research on the Psychological Intervention of Music Therapy for middle school Students' Examination Anxiety [D]. Tianjin Conservatory of Music,2014. DOI: CNKI: CDMD:2.1014.258572 
[15] He Jin. Clinical Study on combined intervention of auricular Point pressing and Five-element Music on exam anxiety [D]. Guiyang College of Traditional Chinese Medicine,2012.

[16] Li Xiaoxia. A Study on the Guidance of the combined model of kinesiology and music therapy for junior high School students' exam anxiety [D]. Nanjing Normal University,2017. DOI: CNKI:CDMD:2.1018.265974

[17] Zhu Xiaofeng. Study on systematic Desensitization combined with Music in the Treatment of High School Students' Examination Anxiety [J]. Medical Theory and Practice,2003(01):34-35. DOI: 10.3969/j.issn.10017585.2003.01.015

[18] Liu Xiao-chen. Clinical Study on the adjustment of Somatosensory Music Therapy to exam anxiety of students preparing for exams [D]. Binzhou Medical College,2018.

[19] Spielberger, Charles. (2010). Test Anxiety Inventory Manual. DOI:10.1002/9780470479216.corpsy0985.

[20] Sarason, I. G. (1978). The Test Anxiety Scale: Concept and Research. In C. D. Spielberger, \& I. G. Sarason (Eds.), Stress and Anxiety (Vol. 5, pp. 193-216). Washington DC: Hemisphere. 